\title{
The Analysis of Service Quality on Building Permit on Soppeng Regency, Indonesia
}

\author{
Alyas \\ Lecturer School of Economics YPUP Makassar \\ Accepted: March 05, 2015 \\ Doi:10.5296/ jpag.v5i1.7315 URL: http://dx.doi.org/10.5296/ jpag.v5i1.7315
}

\begin{abstract}
The study aims to find out service quality on building permit in Soppeng Regency. Population taken out for the study is community inhabiting Soppeng Regency, and the sample is taken out accidentally. Data collection methods applied are observation, questionnaire, interview and documentation. Data analysis technique applied is descriptive quantitative analysis, and the data is presented in form of table. The findings indicate that the service quality on building permit in Soppeng Regency is $67.25 \%$ or is categorized as fairly good based on the indicators of simplicity, on-time service, open, and indiscriminative deal to the community. However, based on the efficiency and economic service quality, it is still poor. There are still many people who are not served efficiently when service hours are not scheduled at the same time as office hours during the process of proposing plan to begin construction. Besides, the rate charged to the community in arranging building permit is high enough in addition to uneconomical. Therefore, in order to improve the service quality on building permit in Soppeng Regency, the local government has to provide dependable professional staffs who are able to serve those people in proposing building permit in simple, on-time, open, indiscriminative, efficient and economical.
\end{abstract}

Keywords: Service quality, Building permit, Soppeng Regency 


\section{Introduction}

The government effort in organizing permit service is intensively proactive by issuing Presidential Instruction No. 5/2004 on acceleration of corruption eradication. The program is motivated by research findings from some parties including foreign research institute indicating that some obstacles are formed during the process of proposing building permit in Indonesia, they are high cost administration, intricate procedures, too many requirements, complicated processing steps, and also uncertain and time consuming completion.

In this case, the government policy to improve public service quality shall be planned in transparent, and the duties and functions of supervisor authority shall be made effective. Thereby, it will be in expectation that the service quality will be improved.

Public demand on the government staffs' service quality will be higher considering that political consciousness on the government rights is developing. The society demands a fast, proper, fair, transparent, efficient and effective service from them. The first and foremost point to be done is by making society understand that the government staff is the servant of the people, and it is not the society who serves the government staff. It implies that public service management improvement is urgent to be carried out by the governmental organization.

Based on the presidential instruction of the Republic of Indonesia No. 01/1995 on the government officials service improvement, in purpose to reform the falling down the image of government which is lately causing more concern, it is urgent to arrange a breakthrough effort in providing services for the society. The effort is, at least, a form of answering to so many challenges, especially in permit service implementation for efficiency and effectiveness.

Local government policy in form of Regent Decrees issued by the regent has been arranged and enacted in Soppeng Regency. The decree No. 3302/XI/2009 outlines retribution fee for building permit. Legal consideration on the formation and decision making of the Regent Decree No. 3302/XI/2009 aims to construct building design that corresponds to the spatial zoning plan applied in Soppeng Regency. Expectation to the formation of the Regent Decree No. 3302/XI/2009 is to implement the decree properly and to realize its objectives in order to provide services for society and to make contribution to the regionally generated revenue of Soppeng Regency.

The Integrated Services Office at Soppeng Regency, as a public service institution other than its function to gain the regionally generated revenue, also makes some effort to improve public service quality in an expectation that the local revenue gained from services sector will escalate and give great contribution to the implementation of regional autonomy. One of the services provided by the Integrated Services Office of Soppeng Regency is by giving recommendation for building permit processing. The location where the Integrated Services Office is in the downtown of Soppeng Regency and central business district makes the need of recommendation for building permit high.

In fact, there are some weaknesses in general that become naked issues about services given 
by the government staffs. The weaknesses found are: illegal retribution out of the service charges outlined in the regional regulations, biased provision of services by the government staffs, and delayed job completion due to lack of means and infrastructure support.

Considering the main function of the government in providing public services, the government shall set orientation to satisfy the society they served. According to the Minister of Efficient Utilization of State Apparatus No. 63 of 2003 on the Guidelines for Minimum Service Standards Implementation, it outlines that every minimum service standard implementation shall be standardized and published as a warranty for service receiver. Service standard is a standardized measurement described in the minimum service standards, and it has to be obeyed by both service provider and receiver in conformity with the public service outlined. The minimum service standards have to be simple, on-time, open, indiscriminative, efficient, and economical.

Grand theory as the basic theory in conducting this study concerning minimum service standard refers to "service" theory proposed by Rafael Jr. Atep (2004: 185) states that in the success of public satisfaction accomplishment, every organization provides the services based on the appropriate mechanism and procedure.

Darajatun (2004: 59) states that the minimum service standard implementation provided by the state apparatus in public service still becomes the focus of public attention. To meet public satisfaction, the service they provide seems still indolent. For the society, although various steps toward the service quality improvement and development has been done by the government, it has not been totally maximized. There are many complaint and criticism from society regarding, especially, intricate service procedures and system. People suppose that the bureaucratic is made complicated on purpose to allow illegal retribution in addition that the job completion seems uncertainly arranged. Worse, the state apparatus/government staffs' attitude seems to be authority-minded that people shall honor them.

Human resource-based service improvement in implementing minimum service standard has an expectation to reform the image of government before the society. If the minimum service standard quality goes better to a part of community, it becomes one of benchmarks for government service credibility to meet public service satisfactory. Public service implementation carried out by the state apparatus in any service aspects has not meet the public expectation, or public service satisfaction that shall be simple, on-time, open, indiscriminative, efficient and economical (Martopo, 2004: 122).

Concerning the problems described above, research problem in this study is, "how is the service quality on building permit in Soppeng Regency?". Thereby, objective of the study is to find out service quality on building permit in Soppeng Regency.

Sutopo (2000: 4) states that characteristic of quality are: (a) Service hours consistency, including waiting and processing time, (b) Service accuracy, including zero mistakes, (c) Polite and warmth behavior in delivering the service, (d) Ease of receiving service, for example availability of many staffs who stand behind the service desk and supporting facilities like computers, (e) Service accomplishment in comfort relating to location, service 
desks, parking lot, availability of information, and so forth, and (f) Service supporting attributes, such as comfortable and clean waiting room, etc.

Service quality or grade constitutes conformity between expectation and or will and reality. In reference to the characteristic above, Soedarsono et al. (2009: 5) proposes dimensions attributed to service quality: (a) Abstract: appearance of physical facilities, equipments, employee, and communication subject, (b) Tested capability, designating reliable and accurate service as what has been appointed, (c) Responsiveness: a will to assist customer and provide service immediately, (d) Skill: owns required competence and knowledge to deliver services, (e) Warmth: well mannered, respectful, attentive and friendly attitude, (f) Credibility: sincerity, trust, honesty, and service granting, (g) Security: risk- and hesitancy-free, (h) Access: ease of communication and approach, (i) Communication: delivers understandable knowledge to customers and gets ready to listen them, and (j) Understanding: tries to be acquainted with customers along with their needs.

The minimum service standards are a set of program that becomes policy for the government in delivering public service to the society in purpose to convey formulation, implementation and evaluation of any policies to the destination, i.e. society.

The guideline for minimum service standards outlines service elements such as simple, on-time, distributed fair justice (indiscriminative), efficient and economical factors in delivering service to broad society. Thereby, contribution to the service will not be a burden to financial aspect (Martopo, 2004: 122). It agrees with Aditama (2003: 52) stating that the society demands simple, on-time, open, fair and equal, efficient and economical services. Accordingly, the service will meet public demand and also give positive contribution on the service they received.

\section{Research Methodology}

The study is carried out in Soppeng Regency, South Sulawesi from March to April, 2014. Population is entire society in Soppeng Regency who are in the process or in the progress of building permit. Due to unclear quantity of sample, it applies accidental sampling technique meaning that whoever in presence can be taken out as a sample as long as the sample is qualified or suitable as data source (Sugiyono, 2006: 60). The techniques applied in data collection are observation, interview, questionnaire and documentation. Data analysis technique applied is descriptive quantitative analysis, and the data is presented in form of table.

\section{Findings and Discussion}

The service quality on building permit in Soppeng Regency formulates the implementation of excellent service quality on building permit for society. The service giving shall be simple, on-time, open, indiscriminative, efficient, and economical. The service quality on building permit constitutes particular arrangement or order that is developed to regulate service procedures and processes and used as a guideline and instruction in delivering service. Based on the calculation, the service quality degree on building permit in Soppeng Regency is 67.25 percent, or it is categorized as Fairly Good. It is assessed based on service giving that is 
simple, on-time, open, indiscriminative, efficient and economical. For more details, below is the explanation.

\subsection{Simple Service Quality}

The findings found service quality indicator for simplicity 74.72 percent, or it is categorized as Fairly Good. Simplicity implies that building permit procedure through the Integrated Services Office shall be understandable, fluent, straightforward, and clear where both staff and society consider the public service a simple activity. Considering the percentage attainment, it indicates that in proposing a building permit, a portion of society has experienced fairly simple service giving. In this case, society finds that the service is easily understandable when the staffs deliver all sorts of services fast in accordance with the arranged procedures and mechanisms in intricate-free. This simplicity lets society receive the building permit services in fairly satisfied when they propose building permit through the Integrated Services Office at Soppeng Regency.

As described above, simple service quality is on the presence of efforts made by every staff in delivering services by following appropriate service procedures in simple, swift, straightforward and understandable. The efforts have to be done to deliver best services to building permit applicants. It agrees with Ashilah (2003: 49) where simplicity means simplified form, characteristic and process of services, and also burden- and difficulty-free. Purposely, the operational stages of the organization will be easily applied in operational, managerial and technical aspects. Simply put, simple service activity must not be intricate and too distinctive.

\subsection{On-time Service Quality}

On-time means the service is carried out by the staffs by taking time-use into consideration while delivering satisfying services to building permit applicants. On-time service quality signifies that building permit arrangement is not time-consuming and the service can be handled at a short time by developing all sorts of services that complies with the service requirements. Thereby, it can be served on time to meet the pre-determined deadline.

The findings found that the service quality degree is 65.36 percent or is categorized as fairly good on time-use aspect. The percentage attainment indicates that the service, based on the time consistency, has not optimized maximum. Therefore, in order to implement on-time service process, service requirements shall be prepared conforming with an on-time service demand.

As described above, on-time service quality is determined by the service requirement compliance to which the requirement makes service process easy and well-managed. Thus, those people who are proposing building permit can get an access easily in fast and swift service completion.

Therefore, on-time service is carried out to prevent inconsistent service activity, inefficient service time and monotonous service giving. The service shall be delivered on time since on-time service has been scheduled based on time use and volume of served customers 
(Wardoyo, 2004: 150).

\subsection{Open Service Quality}

The findings indicate that open service quality is determined by transparent service, clear information and definite service; it attains 63.79 percent, and it is categorized as fairly good. Accordingly, the society who is, in general, proposing building permit has not experienced maximum open service. In other words, there are some staffs who do not give any certainty to the service they give.

Open service quality is a service activity to which it shall be delivered. Open service has to be given complying with the applied form of service. Basically, open service means a service delivered to the society in transparent way by giving service away that complies with openness principles in any applied procedures and mechanisms. It is the the procedure and mechanism that forms service certainty.

Thereby, the government has to be conscious of public demand on transparency in delivering the service. Transparent service signifies an open service where openness becomes a specific characteristic in delivering the service. Purposely, the service will be carried out to the applied procedures and mechanisms at which openness becomes special characteristic of the policy adopted by an organization. Openness as the primary service standard is an important and necessary part in performing an image of standardized service activity complying with the minimum service standards as the guideline for governmental organization.

\subsection{Indiscriminative Service Quality}

According to the findings, indiscriminative service quality reaches 68.82 percent or fairly good. It indicates that the society in Soppeng Regency, in the process of proposing building permit, has experienced indiscriminative service from the staffs. However, there are still some people who perceive that the staffs of building permit office have been discriminative and unfair.

Indiscriminative service quality also means to serve everyone without discriminating people's status to whom they serve or to the society who has an interest on receiving building permit service. Indiscriminative service is required to deliver satisfying service to every building permit applicant by setting out a kind of service according to the building permit applications proposed/filled in by the society as well as the requirements they shall fulfill.

Basically, in carrying out service activity and delivering it to public, an organization shall be aware of its obligation that service giving is obtained and received in pleasure by all walks of life. The service has to be distributed evenly for the equity of everyone, or in the other word, every service activity shall be equally fair.

Indiscriminative service constitutes a form of service for society or public service where every citizen has a right to receive fair service deal without discriminating against race, religion or ethnic. Simply put, evenly fair service means indiscriminative, or a public service which does not discriminate person at his status, economic power or other factors to which the factors can distinguish between individuals from one society and others. 
Fundamentally, service activity must not discriminative. Indiscriminative constitutes an interpretation where, for an organization, the service activity is destined for all walks of life; it shall be universally received by everyone without distinguishing between one service and others.

\subsection{Efficient Service Quality}

Efficient service quality means a condition when service is delivered at working hour in efficient and all applicants can be served well. Then, all building permit applicants must not wait so long to receive the service from the state apparatus. Efficient service quality has to take working hour use into consideration in delivering an efficient service process according to the society and the staffs for building permit proposal accomplishment.

The findings found that efficient service quality degree is 42.37 percent or poor. It signifies that there are still many staffs who do not deliver a fast and accurate service to public. It is supported by interview result from some informants that they do not receive an efficient service. During the process of time-consuming building permit, it takes time more than the pre-determined deadline ( 7 work days).

Public opinion on efficient service quality has not made society satisfied, especially in understanding the use of available working hour and work day in delivering a fast, swift, and convenient service to society. In delivering efficient service performance to public, the Integrated Services Office keeps improving an efficient service during service hours and gets the benefit from the service they deliver. Forms of service activity are usually developed on the use of service hours by delivering a fast, swift and convenient service to issue Building Permit certificate for the applications proposed by public.

For some service receivers, several forms of service activity are inefficient when the benefit and purpose are not consistent with the service hours people need. Every service described in the minimum service standards attempts to deliver an efficient service to public in compliance with the benefit and purpose in performing a series of service activity. Zulkifli (2002:16) states that: A service requires a presence of efficiency; efficiency in every form of service aims to take its benefit and purpose into account that the service will not be useless or the service will not be constructive in gaining service compatibility received by people.

An efficient service activity shall point out a presence of value-based use and benefit becoming an important and worth moment in every service activity. It is fundamental where a service activity means an activity to assess the presence of value-based use and benefit on the activity performed. Then, both service provider and receiver get the benefit and use from the service activity carried out.

\subsection{Economic Service Quality}

Economic means a service delivered complies with the assessment of reasonable cost charged to the Building Permit applicant. Economic, in this case, implies affordable cost and tariff as described in the procedure. Every financing activity shall be measurable as well as costing standard determined and charged to every Building Permit applicant. Costing is determined 


\section{MInstitute Macrothin}

based on building asset financing if the building belongs to the government or socio-religious asset. Besides, there is administration cost according to the building stipulation if it is one-storey building or with no storey at all, construction cost of the site plan, building construction cost, cost of Building Permit board. The expenses are charged to applicant as a requirement to receive costing proposal on Building Permit. Approval of the cost proposal will result in the issue of Building Permit license.

Based on the findings, economic service quality is 40.22 percent or poor. It indicates that the service is less economic. Tariff costing in proposing Building Permit application describes the cost charged to meet various proposal requirements, or it is a step to which form is filled in and service requirements are met to receive the Building Permit service. All process requires cost to complement administration requirements of the Building Permit proposal.

A service activity in organization is not separated from cost and budget expenditures. It is advisable to take conscious thought and plan in delivering the service to produce a maximum output without sacrificing anyone, they are applicants in this case who receive the service. The service shall not make any burden on service receiver as the assessor of the service.

One of aggravating and worry-free services experienced by public is a form of economic service, a service when administration cost is affordable. If it is economic, the service activity will become a reference in defining the cost of service activity. Everyone who receives service attempts to prevent expensive, costly and illogical cost. Consequently, public tends to criticize and complain of such high cost.

\section{Conclusion and Suggestion}

\subsection{Conclusion}

According to the findings, it can be concluded that service quality degree on building permit in Soppeng Regency is fairly good considering the indicators of simple, on-time, open, indiscriminative service giving. Relating to efficient and economic service, however, it is poor. There are still many staffs who give service out of service hours. For public point of view, such service is less efficient in the process of proposing building permit. Besides, the rate charged to the community in proposing building permit is high enough and uneconomic.

\subsection{Suggestion}

In order to improve the service quality on building permit, it is advisable when the local government makes dependable and professional staffs available, i.e. the staffs who can serve in simple, on-time, open, indiscriminative, efficient, and economic ways to everyone who proposes Building Permit application.

\section{References}

Aditama, Chandra, Yoga. 2003. Manajemen Administrasi Rumah Sakit. Jakarta: Penerbit Universitas Indonesia (UI-Press). 


\section{Macrothink}

Journal of Public Administration and Governance ISSN 2161-7104 2015, Vol. 5, No. 1

Atep, Adya, Barata, 2004, Dasar-dasar Pelayanan Prima, Jakarta: PT. Elex. Media Komputindo.

Darajatun, B, 2004. Manajemen Pelayanan Umum di Indonesia, Jakarta: Gunung Agung..

Martopo, 2004. Pelayanan Administrasi Publik. Yogyakarta: Andi.

Soedarsono, 2009. Pelayanan Publik, Pemerataan, dan Administrasi Negara baru, Jakarta: Prisma.

Sotopo, M, 2000. Kinerja Pelayanan dan Pelayanan Prima. Jakarta: Penerbit Jaya pustaka.

Sugiyono. 2006. Statistika untuk Penelitian. Bandung: CV Alfabeta

Wardoyo, T, 2004. Bentuk-bentuk Pelayanan Minimal Suatu Organisasi. Jakarta: Penerbit Mandar Maju. 